\title{
JUMLAH DANA ZAKAT DAN FAKTOR-FAKTOR MAKROEKONOMI YANG MEMPENGARUHINYA1)
}

\author{
Kiki Novitasari \\ Program Studi Ekonomi Islam-Fakultas Ekonomi dan Bisnis-Universitas Airlangga \\ Email: kiki-novitasari-feb13.web.unair.ac.id \\ Suherman Rosyidi \\ Departemen Ekonomi Syariah-Fakultas Ekonomi dan Bisnis-Universitas Airlangga \\ Email: suherman.rosyidi@feb.unair.ac.id
}

\begin{abstract}
The aim of this study was to know the impact of macroeconomic indicators changes toward the total amount of collected zakah in BAZNAS during the period 2012-2016. This study uses qualitative approach by using liniear regression analysis technique. Futhermore dependent variable used in this study is the amount of zakah, while the independent variable are inflation, gold price, money supply and industrial production index. The determination of sampling uses non probability sampling with saturated sample method, on the other hand, the whole population was used as the sample of this study. Moreover, the data used in this study is secondary data.

Keywords : Inflation, Money Supply, Gold Price, Industrial production Index, Amount of Zakah Funds
\end{abstract}

\section{PENDAHULUAN}

Kemiskinan merupakan salah satu permasalahan yang dihadapi oleh bangsa Indonesia. Tidak hanya masalah kemiskinan saja, namun Indonesia pernah mengalami masalah yang sangat krusial di masa orde baru tahun 1998. Krisis ekonomi yang bergejolak pada masa orde baru mengakibatkan stabilitas ekonomi Indonesia mengalami kepailitan. Indikator makroekonomi yang turut mempengaruhi krisis moneter 1998 ialah tingkat inflasi yang tinggi dan tidak dapat terkendalikan. Inflasi merupakan penyakit ekonomi yang tidak dapat dianggap ringan, kerena dapat menimbulkan dampak yang luas. tingkat inflasi di Indonesia terus mengalami peningkatan dan penurunan yang siginifikan. Hal ini menunjukkan kurang efektifnya kebijakan

Bank Indonesia dalam menjaga kestabilan tingkat inflasi tersebut. (BPS: 2013) "Peningkatan inflasi tertinggi terjadi pada tahun 2013, hal ini disebabkan oleh pemerintah yang menetapkan kebijakan pengurangan subsidi BBM yang menyebabkan kenaikan harga pada BBM bersubsidi". Maka laju inflasi dapat menyebabkanmelonjaknya harga kebutuhan pokok dan akan membuat masyarakat jatuh miskin. Menurunnya daya beli masyarakat tidak hanya berdampak pada kualitas hidup dalam pemenuhan kebutuhan pokok saja, melainkan juga berpengaruh terhadap pemenuhan kewajiban umat muslim dalam membayar zakat. Hal ini dapat terjadi karena masyarakat lebih mementingkan kebutuhan pokok terlebih 
Novitasari, et al/Jurnal Ekonomi Syariah Teori dan Terapan Vol. 5 No. 9 September 2018: 739754;JUMLAH DANA ZAKAT DAN FAKTOR-FAKTOR MAKROEKONOMI YANG MEMPENGARUHINYA

dahulu, karena adanya inflasi, harga bahan-bahan pokok menjadi sangat mahal. Akibatnya penghasilan masyarakat yang berpendapatan tetap menjadi berkurang sehingga mengakibatkan orang yang pada mulanya mampu membayar zakat menjadi tidak mampu membayar zakat (Baznas: 2013).

Sementara itu, dunia perzakatan di Indoensia mengalami perkembangan yang lebih baik. Hal ini dapat dilihat dari pembaharuan UU No. 38 tahun 1999 tentang pengelolaan zakat menjadi UU No. 23 tahun 2011 tentang pengelolaan zakat dengan lebih memperbaiki sistem regulasi pengumpulan dana zakat yang sebelumnya dilakukan secara terpisah oleh LAZ dan BAZ menjadi tersentralisasikan di tangan pemerintah, yaitu melalui BAZNAS, sedangkan kedudukan LAZ hanya sebagai pembantu BAZNAS dalam menjalankan tugasnya. Dalam Islam pun sudah dijelaskan bahwa zakat merupakan rukun Islam ketiga yang wajib bagi setiap umat muslim. Seperti yang dijelaskan pada Surat At-Taubah ayat 71

Artinya: Dan orang-orang yang beriman, lelaki dan perempuan, sebahagian mereka (adalah) menjadi penolong bagi sebahagian yang lain. Mereka menyuruh (mengerjakan) yang ma'ruf, mencegah dari yang munkar, mendirikan shalat, menunaikan zakat dan mereka ta'at pada Allah dan Rasul-Nya.Mereka itu akan diberi rahmat oleh Allah; sesungguhnya Allah Maha Perkasa lagi Maha Bijaksana "(At-Taubah:71) (Depag, 2009)
Secara periodik penghimpunan dana zakat mengalami peningkatan secara periodik. Hal ini dilihat dari data yang tercatat di BAZNAS 2012-2016. BAZNAS yang telah memproyeksikan penghimpunan bahwa dana zakat dari para muzakki pada tahun 2016 dapat mencapai Rp 5 triliun. Sampai saat ini proses kalkulasi penghimpunan dana zakat masih terus dilakukan. Penggunaan sistem pelaporan ini sesuai dengan UU No. 23 tahun 2011 tentang pengelolaan zakat, di dalam undang-undang tersebut seluruh lembaga zakat di Indonesia diwajibkan untuk menyerahkan laporan zakat kepada BAZNAS.

Dana ZIS yang terdata di SIMBA BAZNAS dari tahun 2012-2016 menunjukan bahwa penghimpunan dana zakat telah mengalami peningkatan sebesar RP. 264 miliar atau $1270,45 \%$. Untuk dana infaq sedekah perorangan, jumlah dari tahun 2012 hingga 2016 juga mengalami peningkatan sebesar Rp 80,3 miliar atau 5706,85 persen. Di sisi lain total penghimpunan ZIS perorangan mengalami peningkatan sebesar Rp 344,3 miliar atau 1551.91 persen. Peningkatan terbesar terjadi pada tahun 2014 yaitu mencapai 463,35 persen. Peningkatan yang sangat signifikan baik pada zakat maupun infaq sedekah perorangan ini dapat disebabkan oleh banyak faktor. Setidaknya ada dua faktor yang menyebabkan peningkatan ini. Pertama, semakin berkembangnya SIMBA sehingga perkembangan data riil penghimpunan 
Novitasari, et al/Jurnal Ekonomi Syariah Teori dan Terapan Vol. 5 No. 9 September 2018: 739754; JUMLAH DANA ZAKAT DAN FAKTOR-FAKTOR MAKROEKONOMI YANG MEMPENGARUHINYA

zakat terkini dari berbagai daerah di Indonesia akan semakin baik. Kedua, semakin meningkatnya kesadaran masyarakat untuk menunaikan kewajiban zakatnya melalui BAZNAS dan LAZ resmil Baznaz : 2016) . Melihat adanya peningkatan dana yang terhimpun pada baznas dan faktor faktor makroekonomi yang turut andil dalam proses pengumpulan dana zakat nasional yang terkumpul pada BAZNAS, maka penulis tergerak untuk melakukan penelitian dengan judul Pengaruh Indikator Makroekonomi terhadap Jumlah Dana Zakat di BAZNAS periode 2012-2016. Berdasarkan permasalahan yang telah dijelaskan oleh peneliti di atas, maka pertanyaan penelitian adalah sebagai berikut : Apakah inflasi, jumlah vang beredar, harga emas dan indeks produksi industri secara parsial mempengaruhi besarnya jumlah zakat yang terkumpul di Baznas? Apakah inflasi, jumlah vang beredar, harga emas dan indeks produksi industri secara simultan mempengaruhi besarnya jumlah zakat yang terkumpul di Baznas?. Adapun tujuan dari penelitian ini melihat pengaruh secara parsial variabel inflasi, jumlah uang beredar, harga emas dan indeks produksi industri terhadap jumlah dana zakat yang terkumpul di BAZNAS periode 2012-2016 dan melihat pengaruh secara simultan variabel inflasi, jumlah vang beredar, harga emas dan indeks produksi industri terhadap jumlah dana zakat yang terkumpul di BAZNAS periode 2012-2016.

\section{LANDASAN TEORI}

Zakat (zakah) secara bahasa bermakna 'mensucikan','tumbuh' atau 'berkembang.menurut pendapat Wibisono (2015:1) " Zakat (zakah) secara bahasa bermakna 'mensucikan', 'tumbuh'atau 'berkembang'. Menurut istilah syara' zakat bermakna mengeluarkan sejumlah harta tertentu untuk diberikan kepada orang-orang yang berhak menerimanya (mustahik) Jadi zakat yang telah didapatkan akan disalurkan kepada delapan asnaf yang berhak mendapatkan zakat sementara itu menurut Undang-Undang Nomor 23 Tahun 2011 tentang Pengelolaan Zakat Pasal 1 ayat (2) "zakat diartikan sebagai harta yang wajib dikeluarkan oleh seorang muslim atau badan usaha untuk diberikan kepada yang berhak menerimanya sesuai dengan syariat islam".

Yusuf Qardhawi (2004) dalam Hafidhuddin (2002) yang menjelaskan "...bahwa zakat adalah milik masyarakat, karena mendapatkannya adalah hasil usaha bersama masyarakat...".Maka seperti yang sudah di tegaskan dalam Al Quran bahwa zakat tidak hanya sebagai kewajiban dalam menunaikan ibadah namun juga sebagai instrumen yang dapat mengatasi masalah sosial dan dapat mengangkat kehidupan terutama untuk si miskin agar tidak selalu merasa kekurangan dan untuk si kaya sebagai salah satu wujud bersyukur dan tolongmenolong antara umat manusia. 
Novitasari, et al/Jurnal Ekonomi Syariah Teori dan Terapan Vol. 5 No. 9 September 2018: 739754;JUMLAH DANA ZAKAT DAN FAKTOR-FAKTOR MAKROEKONOMI YANG MEMPENGARUHINYA

Al-Zuhayly (2008:126) menjelaskan bahwa zakat diwajibkan terhadap kelima jenis harta, yaitu: 1. Nuqud (emas, perak, dan vang). 2.Barang tambang dan barang temuan. 3. Harta perdagangan.Perhitungan zakat perdagangan disesuaikan dengan harga barang ketika zakat dikeluarkan, bukan dengan harga saat pembelian. 4. Zakat tanaman dan buah-buahan diwajibkan karena tanah yang ditanami merupakan tanah yang bisa berkembang, tanaman bisa tumbuh dari tanah tersebut. 5. Al-Zuhayly (2008:225) menjelaskan bahwa syarat wajib zakat ialah binatang ternak adalah unta, sapi dan kambing yang jinak.

6. Zakat Kontemporer. Hafidhuddin (2002:91) menjelaskan bahwa "...di era modern saat ini ada beberapa hal yang dapat dizakati, yaitu zakat profesi, zakat perusahaan, dan zakat surat berharga...". berikut ini merupakan zakat profesi.

a) Zakat Profesi

Zakat Profesi termasuk dalam kategori zakat mal. Yusuf Qardhawi dalam Haafidudin (2002) menyatakan: "Pada saat ini penghasilan atau pendapatan yang diusahakan melalui keahliannya, baik keahliannya yang dilakukan secara sendiri maupun secara bersama-sama. Yang dilakukan sendiri misalnya profesi dokter, arsitek, ahli hukum, penjahit, pelukis. Yang dilakukan secara bersama-sama misalkan pegawai (pemerintah maupun swasta) dengan menggunakan sistem upah atau gaji". b) Zakat Perusahaan

Pada saat ini hampir setiap perusahaan tidak dikelola secara individual, melainkan secara bersamasama dalam organisasi dan manajemen yang modern, misalnya dalam bentuk PT, CV atau koperasi. Dalam kewajiban zakat perusahaan ada tida hal yang mendasari pemungutan zakat pada perusahaan. Pertama, perusahaan menghasilkan produk tertentu jika dikaitkan dengan kewajiban zakat maka produk yang dihasilkan haruslah halal, contohnya perusahaan alat bangunan, kesehatan dan lainya. Kedua, perusahaan yang bergerak di bidang jasa seperti transportasi, travel dan lainya. Ketiga, perusahaan yang bergerak di bidang keuangaan seperti lembaga keuangan (bank, asuransi, money changer dan lainya.

Badan Amil Zakat Nasional (BAZNAS) merupakan badan resmi dan satu-satunya yang dibentuk oleh pemerintah berdasarkan Keputusan Presiden RI No. 8 Tahun 2001 yang memiliki tugas dan fungsi menghimpun dan menyalurkan zakat, infaq, dan sedekah (ZIS) pada tingkat nasional Lahirnya Undang-Undang Nomor 23 Tahun 2011 tentang Pengelolaan Zakat semakin mengukuhkan peran BAZNAS sebagai lembaga yang berwenang melakukan pengelolaan zakat secara nasional. Dalam UU tersebut, BAZNAS dinyatakan sebagai lembaga pemerintah nonstruktural yang bersifat mandiri dan bertanggung jawab kepada Presiden 
Novitasari, et al/Jurnal Ekonomi Syariah Teori dan Terapan Vol. 5 No. 9 September 2018: 739754;JUMLAH DANA ZAKAT DAN FAKTOR-FAKTOR MAKROEKONOMI YANG MEMPENGARUHINYA

melalui Menteri Agama. Dengan demikian, BAZNAS bersama Pemerintah bertanggung jawab untuk mengawal pengelolaan zakat yang berasaskan: syariat Islam, amanah, kemanfaatan, keadilan, kepastian hukum, terintegrasi dan akuntabilitas.

Terdapat banyak indikator makroekonomi. Pada penelitian ini indikator makroekonomi yang akan dibahas hanyalah yang secara teoritik memiliki hubungan kausalitas dengan variabel dependen yaitu inflasi, harga emas, jumlah vang beredar dan indeks produksi industri.

Inflasi didefinisikan sebagai kenaikan harga-harga yang berlaku dalam suatu perekonomian dalam waktu yang lama. Hal ini selaras dengan pendapat Rosyidi (2017:131) yang menyatakan bahwa "Inflasi adalah gejala harga yang berlangsung secara terus-menerus. Kenaikan harga yang berlangsung sekali atau dua kali saja lalu reda kembali bukan inflasi namanya". Jadi yang dinamakan inflasi bukan kenaikan harga dalam rangka memperingati hari tertentu yang karenanya permintaan masyarakat meningkat kemudian menyebabkan tingginya harga barang di pasaran dan kemudian setelah permintaan masyarakat menurun harga barang akan menjadi normal kembali. Secara aritmetika, tingkat inflasi adalah presentasi kenaikan harga barang dalam periode tertentu. Menurut Boediono ( 2005: 162) sebab terjadinya inflasi terjadi karena dua hal yaitu demand pull inflation dan cost push inflation kedua penyebab inflasi dapat diterangkan sebagai berikut.

a. Demand Pull Inflation yaitu inflasi yang terjadi karena adanya faktorfaktor yang menggeser permintaan agregat sehingga terciptanya excess demand. Excess demand ialah keadaan dimana kelebihan jumlah permintaan akibat penurunan harga, contohnya harga daging ayam yang awalnya Rp. $32.000 / \mathrm{kg}$ turun menjadi Rp. $30.000 / \mathrm{kg}$ pasca lebaran karena terdapat peningkatan pasokan ayam yang mencukupi. Demand Pull Inflation terjadi apabila terdapat peningkatan permintaan agregat dalam keadaan output full employment akan menyebabkan kelebihan permintaan barang dan jasa, sehingga harga barang dan jasa meningkat. Sementara itu peningkatan terhadap barang dan jasa akan menyebabkan peningkatan faktor produksi, sehingga faktor produksi mengalami peningkatan.

b. Cost push inflation yaitu inflasi yang terjadi akibat adanya faktor-faktor yang menggeser penawaran agregat. Faktor yang menyebabkan terjadinya penawaran agregat disebabkan berbagai macam faktor, mulai dari peningkatan upah, harga barang 
Novitasari, et al/Jurnal Ekonomi Syariah Teori dan Terapan Vol. 5 No. 9 September 2018: 739754;JUMLAH DANA ZAKAT DAN FAKTOR-FAKTOR MAKROEKONOMI YANG MEMPENGARUHINYA

luar negeri dan harga barang impor. Kenaikan upah menyebabkan adanya peningkatan biaya produksi dalam membayar pekerja, hal ini menyebabkan harga barang menjadi tinggi kerena produsen membebankan kenaikan upah kepada konsumen. Supply side inflation dapat disebabkan karena perusahaan memiliki kekuatan untuk memonopoli untuk menaikkan harga jual barang dan jasa seningga menigkatkan profit margin. Sedangkan dengan adanya negara lain mengekspor barang ke Indonesia akan menyebabkan terjadinya kenaikan atas barang impor Indonesia dari negara tersebut. Maka hal ini akan menyebabkan inflasi yang disebut dengan impor cosh push inflation.

Jenis vang yang sejak lama digunakan di berbagai negara sejak beberapa abad yang lalu, adalah mata vang emas dan perak. Emas dan perak memiliki ciri-ciri yang diperlukan untuk menjadi mata vang yang baik. Hal ini selaras dengan pendapat Nurshuhaida dan Zaiton, (2013:1275) "Gold dinar cannot be inflated by printing more of it because it is natural resources not like fiat money; it cannot be devalued by goverment decree". Karena keistimewaannya itu maka emas dan perak telah terbukti sepanjang sejarah sebagai alat tukar yang nilainya sangat stabil.

Jumlah uang beredar (JUB) atau disebut penawaran uang (money supply) adalah jumlah dari keseluruhan vang yang berada di tangan masyarakat dan beredar dalam perekonomian negara selain yang dipegang oleh bank dan pemerintah. Jumlah vang beredar dalam arti sempit narrow money $\left(M_{1}\right)$ dan jumlah vang beredar dalam arti luas broad money (M2). Menurut Sukirno (2005:143) penawaran vang dalam arti sempit, jumlah vang beredar $M_{1}$ terdiri dari uang kartal (logam dan kertas) dan vang giral. Uang kartal ialah uang kertas dan logam sedangkan vang giral ialah vang dalam bentuk cek. Sedangkan $M_{2}$ merupakan arti penawaran vang dalam arti luas yang meliputi $M_{1}$ dan ditambah dengan tabungan masyarakat yang di depositokan dalam bank.

Sementara itu menurut Keynes, permintaan uang didasarkan 3 motif yaitu pertama, motif transaksi yang mana permintaan uang untuk keperluan aktivitas sehari-hari. Motif transaksi ini tergantung kepada $Y$ atau pendapatan nasional, atau $L_{T}=f(Y)$ di dalam persamaan taersebut, $L_{T}$ adalah liquidity prefference for transaction motive dan $Y$ adalah pendapatan nasional. Kedua variabel tersebut berhubungan searah atau positif.

Yang kedua adalah motif berjagajaga yaitu motif yang mengantisipasi 
Novitasari, et al/Jurnal Ekonomi Syariah Teori dan Terapan Vol. 5 No. 9 September 2018: 739754;JUMLAH DANA ZAKAT DAN FAKTOR-FAKTOR MAKROEKONOMI YANG MEMPENGARUHINYA

fluktuasi dan ketidakpastian ekonomi di masa yang akan datang. Sebagaimana motif transaksi, motif berjaga-jaga ini juga tergantung kepada $Y$ atau pendapatan nasional sehingga $L_{p}=f(Y)$, dengan $L_{P}$ adalah liquidity prefference for precantionary motive kedua variabel tersebut juga berhubungan searah atau positif. Kedua motif permintaan yang ini, yakni $L_{T}$ dan Lp, karena sama-sama mempunyai fungsi dari $Y$, dijadikan satu dan diberi notasi $L_{1}$. Selanjutnya, motif yang ketiga adalah spekulasi ini disebut $L s$ atau liquidity prefference for speculative motive, dan mempunyai fungsi dari antar bunga atau $L s=f(i)$ dengan i adalah suku bunga. Oleh karena itu Islam tidak mengenal suku bunga, maka dinyatakan bahwa penerimaan vang itu didorong oleh dua motif saja yaitu $L_{T}$ dan $L_{p . .}$

Menurut Fatkhurrozaq (2012:17) dalam skripsi Singgih (2016) "Indeks produksi industri merupakan salah satu indikator yang mencerminkan status ekonomi nasional". Indeks ini menunjukkan volume produksi dan mengukur output industri. Hal ini juga berdampak pada semua indikator makroekonomi. Apabila indeks ini naik, perekonomian sedang tumbuh. Angka indeks produksi industri yang menggambarkan perkembangan produksi sektor industri pengolahan secara lebih dini karena sifatnya dirancang secara periodik bulan. Untuk memantau perkembangan produksi besar dan sedang dibutuhkan beberapa indikator yang dapat mengukur secara konsisten dari waktu ke waktu. Indikator tersebut anatara lain: besaran nilai output dan penyerapan tenaga kerja disamping produktivitas (BPS, 2006).

\section{Hubungan Pengaruh Inflasi Terhadap Jumlah Dana Zakat}

Salah satu permasalahan ekonomi yang sering terjadi di suatu negara adalah inflasi. Definisi inflasi itu sediri dikemukakan oleh Boediono, (1985:155) yang menyatakan bahwa "Inflasi adalah kecenderungan dari harga-harga naik secara umum dan terus-menerus". Jadi, yang dinamakan inflasi bukan kenaikan harga dalam rangka memperingati hari tertentu karena permintaan masyarakat meningkat kemudian menyebabkan tingginya harga barang di pasaran, kemudian setelah permintaan masyarakat menurun harga barang akan menjadi normal kembali. Apabila terjadi kenaikan barang dan jasa akibat inflasi, maka daya beli masyarakat akan barang dan jasa mengalami penurunan. Hal ini terjadi pada masyarakat yang berpendapatan tetap, kenaikan harga barang dan jasa akan menurunkan upah riil yang diterima masyarakat yang berpendapatan tetap. Hal tersebut berdampak pada menurunnya jumlah dana zakat yang dikeluarkan oleh masyarakat, karena masyarakat akan mendahulukan kebutuhan pokok terlebih dahulu. Apabila jumlah muzakki berkurang maka, yang terjadi ialah meningkatnya jumlah mustahia pada suatu negara. Dan apabila itu terjadi dapat dikatakan, 
Novitasari, et al/Jurnal Ekonomi Syariah Teori dan Terapan Vol. 5 No. 9 September 2018: 739754;JUMLAH DANA ZAKAT DAN FAKTOR-FAKTOR MAKROEKONOMI YANG MEMPENGARUHINYA

jumlah penduduk diambang garis kemiskinan bertambah dan kesejahteraan masyarakat di suatu negara akan berkurang. Hal tersebut selaras dengan penelitian yang dilakukan oleh Noviyanti (2016) "Terdapat pengaruh variabel makroekonomi yang signifikan negatif terhadap jumlah dana zIS Dompet Dhuafa".

\section{Hubungan Pengaruh Jumlah Uang Beredar Terhadap Jumlah Dana Zakat}

Dalam kegiatan ekonomi, uang merupakan instrumen yang penting dalam menjalankan transaksi. Ulasan di atas selaras dengan pendapat Zaiton, dan Nurshuhaida (2013) yang menyatakan bahwa "Money was created to facilitate the exchange in economic transactions". Dengan demikian apabila jumlah vang beredar di masyarakat meningkat, bagi hasil akan meningkat dan hal ini akan meningkatkan jumlah investasi. Tidak hanya dapat digunakan sebagai investasi, vang beredar dapat juga diproduktifkan pada sektor riil. Uang yang didayagunakan secara produktif pada sektor riil akan mampu menumbuhkan perekonomian, sehingga dapat meningkatkan pendapatan nasional. Jika pendapatan nasional mengalami kenaikan, maka penerimaan dana zakat akan bertambah. Setelah itu, dana zakat yang terkumpul didistribusikan kepada masyarakat yang berhak menerima. Terdistibusikannya dana zakat sebagai salah satu cara dalam megentaskan kemiskinan. Peneliti yang mendukung teori diatas adalah Noviyanti (2016) yang menyatakan bahwa "Terdapat hubungan signifikan positif variabel makroekonmi terhadap jumlah penerimaan dana ZIS.

\section{Hubungan Pengaruh Harga Emas Terhadap Jumlah Dana Zakat}

Pada zaman modern saat ini penggunaan mata uang emas cenderung ditinggalkan, karena nilai fisiknya yang tidak praktis. Hal ini selaras dengan pendapat Salmy Endawati (2012) dalam jurnal Zaiton dan Nurshuhaida (2013) bahwa "Dinar as Currency, it shows that the implementation of gold dinar as currency in the economy is still not suitable because of the shortcomings in providing for physical infrastructure which is inadequate gold".

Jika harga emas mengalami kenaikan, akan menyebabkan meningkatnya jumlah nisab yang dibutuhkan oleh masyarakat. Hal tersebut terjadi karena pendapatan masyarakat dalam Rupiah sehingga, apabila dikonversi dalam harga emas, pendapatan masyarakat yang memiliki pendapatan tetap akan mengalami penurunan. Jika pendapatan tetap, sedangkan kenaikannya llebih lambat daripada kenaikan harga emas maka hal ini mengakibatkan kemampuan muzakki dalam mencapai nisab akan mengalami penurunan. Hal tersebut akan menjadikan berkurangnya jumlah muzzaki yang membayar zakat sehingga jumlah 
Novitasari, et al/Jurnal Ekonomi Syariah Teori dan Terapan Vol. 5 No. 9 September 2018: 739754;JUMLAH DANA ZAKAT DAN FAKTOR-FAKTOR MAKROEKONOMI YANG MEMPENGARUHINYA

pengumpulan dana zakat mengalami penurunan. Dan penjelasan tersebut dapat disimpulkan bahwa harga emas memiliki pengaruh signifikan positif terhadap jumlah dana zakat. Selaras dengan penelitian yang dilakukan oleh Ahmad (2011) yang mengatakan bahwa "Harga emas memiliki pengaruh signifikan positif terhadap jumlah dana zakat".

\section{Hubungan Pengaruh Indeks Produksi Industri Terhadap Jumlah Dana Zakat}

\begin{abstract}
Pertumbuhan Indeks Produksi Industri merupakan proksi dari pertumbuhan ekonomi Indonesia (BPS, 2000). Apabila pertumbuhan ekonomi Indonesia meningkat maka, pendapatan nasional naik, jumlah dana zakat yang terkumpul akan bertambah. Hal tersebut didukung oleh penelitian Noviyanti (2016) yang menyatakan bahwa "Terdapat hubungan signifikan positif variabel makroekonomi terhadap pengumpulan dana ZIS Dompet Dhuafa"
\end{abstract}

Berdasarkan landasan teori di atas, maka hipotesis dalam penelitian ini adalah

$H_{0}$ : paling tidak satu $\beta_{i}(i=1,2,3,4)>0$

$H_{i}$ : paling tidak satu $\beta_{i}(i=1,2,3,4)=0$

\section{METODOLOGI PENELITIAN}

Penelitian ini dilakukan dengan menggunakan pendekatan kuantitatif, yaitu penelitian yang suatu proses penelitian untuk menemukan pengetahuan yang menggunakan data berupa angka sebagai alat menganalisis keterangan mengenai apa yang ingin diketahui.

Untuk menjawab rumusan masalah dan menguji hipotesis, maka variabel yang digunakan dalam penelitian ini harga emas, jumlah vang beredar dan indeks produksi industri.

\section{Definisi Operasional Variabel}

Untuk memberikan gambaran yang jelas, maka variabel tersebut dapat didefinisikan sebagai berikut.

a. Tingkat inflasi

- Nilai inflasi dinyatakan dalam satuan presentasi. Data inflasi adalah data bulanan tahun 2012-2016 dan merupakan data rasional dan bersifat time series.

b. Jumlah Uang Beredar (JUB)

Data variabel JUB yang digunakan yaitu jumlah uang beredar dalam arti luas $\left(\mathrm{M}_{2}\right)$ selama periode 2012-2016. Data JUB diperoleh dari Bank Indonesia yang dinyatakan dalam satuan miliar rupiah serta menggunakan data bulanan.

c. Harga Emas

.Data ini dapat diakses melalui www.harga-emas.com. Sedangkan untuk variabel harga emas yang digunakan adalah harga emas bulanan dalam rupiah/gram selama periode 2012 sampai 2016.

d. Indeks Produksi Industri (IPI)

Data indeks produksi industri bulanan diambil dari Badan Pusat Statistik (BPS) dan dapat di akses melalui www.bps.go.id selama periode 2012 sampai 2016.

Jenis dan Sumber Data 
Novitasari, et al/Jurnal Ekonomi Syariah Teori dan Terapan Vol. 5 No. 9 September 2018: 739754;JUMLAH DANA ZAKAT DAN FAKTOR-FAKTOR MAKROEKONOMI YANG MEMPENGARUHINYA

Jenis data yang digunakan dalam penelitian ini adalah data skunder time series dengan periode waktu selama 5 tahun yaitu dari tahun 2012-2016. Sumber data berasal dari instasi yang terkait dengan inflasi dan jumlah vang beredar (JUB) diperoleh dari website Bank Indonesia yang dapat diakses melalui www.bi.go.id. Data harga emas diperoleh dari PT. Aneka Tambang,Tbk, yang bergerak di bidang jual beli emas yang dapat diakses melalui www.hargaemas.com. Indeks proyeksi industri (IPI) diperoleh dari Badan Pusat Statistik (BPS), untuk data jumlah zakat yang terkumpul diperoleh dari laporan keuangan Badan Amil Zakat Nasional (BAZNAS) yang dapat diakses melalui www.pusat.baznas.go.id.

\section{Populasi dan sampel}

Penelitian ini menggunakan analisis bulanan (month to month) dan data yang digunakan adalah seluruh data populasi yaitu sebanyak 60 observasi dari periode Januari 2012 sampai Desember 2016. Karena jumlah observasi kurang dari 100 maka diambil semua, sehingga penelitian ini disebut penelitian populasi.

\section{Metode Analisis}

Metode analisis yang digunakan dalam penelitian ini adalah analisis regresi berganda. berikut langkah-langkah yang digunakan:

1. Uji asumsi klasik meliputi : uji normalitas, uji multikoliniearitas, ujiautokorelasi, uji heteroskedastisitas
2. Uji Statistik model meliputi koefisien determinasi(R2)

3.Uji hipotesis dengan menggunakan ujit dan Uji-F

\section{HASIL DAN PEMBAHASAN}

Penelitian dilakukan dengan menggunakan sampel jenuh, dimana seluruh anggota populasi digunakan sebagai sampel. Perhitungan dalam penelitian ini diukur berdasarkan data bulanan inflasi, jub, ipi dan harga emas tahun 2012-2016, serta data bulanan jumlah zakat di BAZNAS, sehingga setiap variabel terdapat 60 data (N) yang diperoleh dalam penelitian ini.

\section{Analisis Statistik Deskriptif}

Tabel 2

Analisis Statistik Deskriptif

\begin{tabular}{|l|r|r|r|r|r|}
\hline & \multicolumn{1}{|c|}{ N } & \multicolumn{1}{|c|}{ Minimum } & Maximum & Mean & Std Deviation \\
\hline Zakat & 60 & 2016175907 & 20460180168 & 5568366032 & 4060657563 \\
JBB & 60 & 2852004,94 & 5004976,79 & 3887251,74 & 615825,8334 \\
\hline Inflas & 60 & 2,79 & 8,79 & 5,5153 & 1,77019 \\
\hline Emas & 60 & 493000 & 605000 & 551270 & 26488,9059 \\
\hline IPI & 60 & $-9,54$ & 8,76 & 0,4578 & 2,97011 \\
\hline Valid N (listwise) & 60 & & & & \\
\hline
\end{tabular}

Sumber: Data Penelitian (diolah)

Secara keseluruhan rata-rata nilai zakat adalah sebesar Rp 5.568.366.032,1333 dengan standar deviasi $4.060 .657 .563,38951$. Nilai standar deviasi menunjukan adanya variasi data dari tiap bulannya. Jumlah minimum zakat adalah Rp 2.016.175.907,00 yaitu pada bulan Juni tahun 2012 sedangkan jumlah maksimum zakat adalah Rp 20.460.180.168 yaitu pada bulan Juni tahun 2016.

Uji Asumsi Klasik 
Novitasari, et al/Jurnal Ekonomi Syariah Teori dan Terapan Vol. 5 No. 9 September 2018: 739754;JUMLAH DANA ZAKAT DAN FAKTOR-FAKTOR MAKROEKONOMI YANG MEMPENGARUHINYA

Pemeriksaan asumsi pertama adalah uji normalitas untuk melihat apakah dalam model regresi, variabel penganggu atau residual memiliki ditribusi normal. Hasil uji normalitas Kolmogorov-Smirnov.

Tabel 3

\section{Hasil Uji Kolmogrov-Smirnov}

\begin{tabular}{c|c|} 
& Unstandarized Residual \\
\hline $\mathrm{N}$ & 60 \\
\hline Kolmogorov-Smimov Z & 1.761 \\
\hline Asymp. Sig. (2-tailed) & 0.004 \\
\hline
\end{tabular}

Sumber : Data Penelitian (diolah)

Data dapat dikatakan berdistribusi normal jika signifikansi menunjukkan lebih dari 0.05. Pada penelitian ini distribusi normal bisa terpenuhi setelah melakukan outlier data yang terdapat di tabel casewise pada SPSS yaitu $31,54,42,55,8$, 19, 20. Berikut adalah hasil uji KolmogrovSwirnov setelah melakukan outlier.

\section{Tabel 4}

\section{Hasil Uji Kolmogrov-Smirnov}

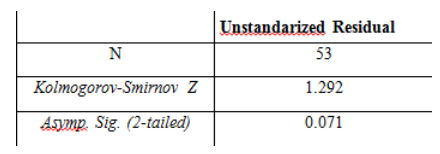

Sumber : Data Penelitian (diolah)

Dapat diperoleh nilai KolmogorovSmirnov 1.292 dengan tingkat signifikansi 0.071. Hal tersebut menunjukkan bahwa data terdistribusi secara normal.

Pemerikasaan asumsi kedua adalah uji multikolinieritas. Untuk mengetahui terjadinya multikolinieritas dapat di deteksi dengan membandingkan nilai $F, R^{2}$ dan $t$.
Mengenai hal ini selaras dengan pendapat (Gujarati, 2010:254).

"High R2 but few significant $\dagger$ ratios. As noted earlier, this is the "classic" symptom of multicollinearity. If $R^{2}$ is high, say, in excess of 0.8 , the $F$ test in most cases will reject the null hypothesis that the partial slope coefficients are jointly or simultaneously equal to zero. But individual $\dagger$ tests will show that none or very few partial slope coefficiants are statistically different from zero..."

Tabel 5

Hasil Uji Multikoliniearitas

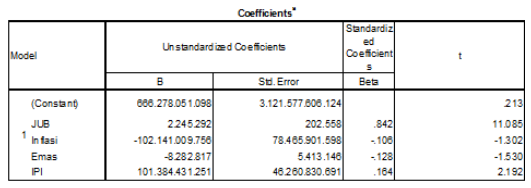

Sumber : Data Penelitian (diolah)

Nilai $†$ pada variabel inflasi sebesar -1.302 sedangkan harga emas sebesar 1.530 dengan nilai sebesar 0,717 . Dengan demikian maka nilai $t$ pada variabel inflasi dan harga emas di bawah 1,96 yang menandakan bahwa telah terjadi multikoliniearitas pada kedua variabel tersebut. Masalah multikoliniearitas perlu ditangani dengan cara membuang variabel yang memiliki nilai $t$ rendah. Anggapan ini selaras dengan pemikiran Gujarati (262:2010) "Faced with severe multicollinearity, the solution might seem to be to drop one or more the collinear variables". Dengan hal tersebut maka 
Novitasari, et al/Jurnal Ekonomi Syariah Teori dan Terapan Vol. 5 No. 9 September 2018: 739754;JUMLAH DANA ZAKAT DAN FAKTOR-FAKTOR MAKROEKONOMI YANG MEMPENGARUHINYA

pada penelitian ini akan membuang dua variabel yang terjangkit masalah multikolinearitas yaitu variabel inflasi dan harga emas. Berikut hasil uji multikolinearitas dengan membuang dua variabel yang bermasalah.

Tabel 6

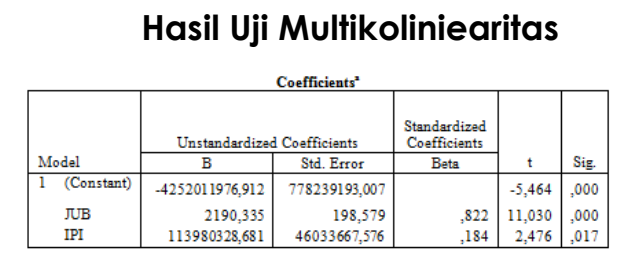

Sumber : Hasil Penelitian (diolah)

Dengan demikian variabel yang saya gunakan dalam penelitian ini adalah jumlah uang beredar dan indeks produksi industri. Seperti yang terpapar pada Tabel 4.6 dapat di ketahui nilai † pada variabel jumlah vang beredar sebesar 11,030 dan indeks produksi industri sebesar 2,476 dengan tingkat signifikansi dibawah 0,005 dan nilai $R^{2}$ sebesar 0,712.

Pemeriksaan asumsi ketiga adalah Uji autokorekasi bertujuan untuk menguji apakah dalam model regresi linier ada korelasi antara kesalahan pengganggu pada periode $t$ dengan kesalahan pengganggu pada periode $t-1$ (sebelumnya). Jika terdapat korelasi, maka dapat dipastikan terjadi autokorelasi. "...untuk mendeteksi adanya autokorelasi digunakan Durbin-Watson (DW)..."(Santoso, 2015:194).

Tabel 7

\begin{tabular}{|c|c|} 
Model & Durbin-Waston \\
\hline 1 & 1,768
\end{tabular}

\section{Uji Autokorelasi}

Sumber : Hasil Penelitian (diolah)

Pada hasil uji autokorelasi diatas dapat diketahui angka Durbin-Waston sebesar 1.768. Maka dapat disimpulkan tidak terjadi autokorelasi.

Pemeriksaan asumsi keempat adalah Uji heterokedastisitas bertujuan untuk menguji apakah terjadi ketidaksamaan varian dari residual satu pengamatan ke pengamatan lain dalam suatu regresi. Pada gambar di atas, titiktitik membentuk pola yang menyebar lalu kemudian menyempit. Dapat diartikan bahwa penelitian ini terbebas dari heterokedastisitas.

\section{Gambar 1}

Hasil uji Autokorelasi

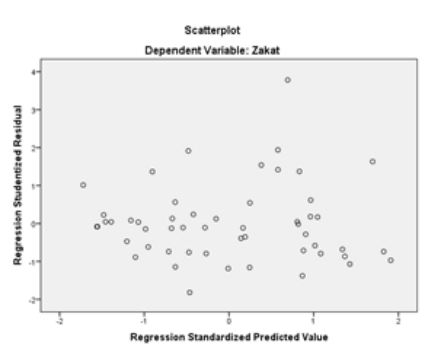

Sumber :Data Penelitian (diolah)

Dilihat pada gambar diatas maka tidak terjadi autokorelasi.

\section{Analisis Regresi Linier Berganda}

Analisis regresi berganda pada penelitian ini diperoleh dengan menggunakan software SPSS 21.

\section{Tabel 8}

\section{Analisis Regresi Berganda}

\begin{tabular}{|c|c|c|c|c|}
\hline Model & Unstandardized coefficients & t & Sig. \\
\hline & B & Std. Error & & \\
\hline (Constant) & $-4252011976,912,2190,335$ & 778239193,007 & $-5,464$ & 0,000 \\
\hline JUB & 2190.335 & 198,579 & 11,030 & 0,000 \\
\hline IPI & 113980328,681 & 46033667,576 & 2,476 & 0,017 \\
\hline
\end{tabular}


Novitasari, et al/Jurnal Ekonomi Syariah Teori dan Terapan Vol. 5 No. 9 September 2018: 739754;JUMLAH DANA ZAKAT DAN FAKTOR-FAKTOR MAKROEKONOMI YANG MEMPENGARUHINYA

Sumber :Data Penelitian (diolah)

Persamaan di atas menjelaskan hasil perhitungan koefisien regresi memiliki nilai konstata sebesar -4252011976,912,2190,335 nilai konstanta tersebut menunjukkan bahwa ketika variabel jumlah vang beredar $\left(X_{1}\right)$ dan Indeks Produksi Industri $\left(X_{2}\right)$ bernilai nol, maka variabel dependen (Y) jumlah dana zakat akan memiliki nilai sebesar $4252011976,912,2190,335$.

\section{Uji Hipotesis}

Uji hipotesis penelitian bertujuan untuk membuktikan kebenaran dari hipotesis yang telah dijelaskan oleh peneliti. Hasil uji hipotesis bertujuan untuk menjawab rumusan masalah yang telah dipaparkan sebelumnya. Uji hipotesis dalam penelitian ini terdiri dari Uji $t$ dan Uji F. Pengujian hipotesis dilakukan dengan progam software SPSS.

Uji + digunakan untuk membuktikan apakah setiap variabel independen secara individu mempengaruhi variabel dependen. Berikut adalah hasil pengolahannya:

\section{Tabel 9}

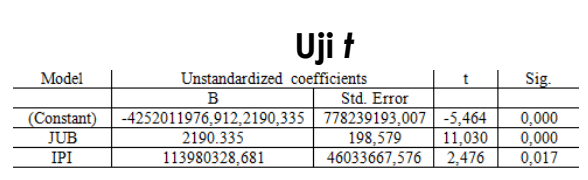

Sumber :Data Penelitian (diolah)

Dari hasil tabel diatas dapat disimpulkan bahwa.
1. Variabel JUB berpengaruh signifikan terhadap jumlah dana zakat.

2. Variabel IPI berpengaruh signifikan terhadap jumlah dana zakat.

Uji $F$ bertujuan untuk mendeteksi signifikansi semua variabel independen secara simultan terhadap variabel dependen.

\section{Tabel 10}

Uji $F$

\begin{tabular}{c|c|c} 
Model & F & Sig. \\
\hline Regression & 65.303 & 0.000 \\
\hline
\end{tabular}

Sumber :Data Penelitian (diolah)

Dari hasil pengujian SPSS maka didapatkan fakta bahwa variabel independen yaitu JUB dan IPI memberikan hasil $F_{\text {hitung }}>F_{\text {tabel }}(65.303>4,03)$ dengan tingkat signifikansi kurang dari 0,005 yaitu $(0,000<0,005)$. Berdasarkan hasil tersebut maka dapat dinyatakan bahwa $H_{0}$ diterima, sehingga dapat disimpulkan bahwa jumlah vang beredar dan indeks produksi industri secara simultan berpengaruh terhadap jumlah dana zakat.

Nilai koefisien determinasi terletak antara 0 dan 1 atau $0<R^{2}<1$. Nilai $R^{2}$ yang kecil atau mendekati 0 berarti kemampuan variabel independen dalam menjelaskan variabel dependen sangat terbatas. Nilai yang mendekati 1 berarti variabel independen memberikan hampir semua informasi yang dibutuhkan untuk memprediksi variasi variabel dependen. Di bawah ini disampaikan tabel yang akan menjelaskan $R^{2}$. 
Novitasari, et al/Jurnal Ekonomi Syariah Teori dan Terapan Vol. 5 No. 9 September 2018: 739754;JUMLAH DANA ZAKAT DAN FAKTOR-FAKTOR MAKROEKONOMI YANG MEMPENGARUHINYA

Tabel 11

uji $R^{2}$

\begin{tabular}{|c|c|c|c} 
Model & $R$ & $R$ Square & $\begin{array}{c}\text { Adjusted } R \\
\text { Square }\end{array}$ \\
\hline 1 & 0,850 & 0,723 & 0,712 \\
\hline
\end{tabular}

Sumber : Data Penelitian (diolah)

Uji $R^{2}$ menunjukkan nilai sebesar 0,172 yang berarti bahwa variasi variabel dependen yaitu jumlah dana zakat dapat dijelaskan oleh variabel independen yaitu jumlah vang beredar dan indeks produksi industri sebesar $71,2 \%$, sedangkan sisanya dijelaskan oleh variabel lain yang tidak dimasukkan dalam model penelitian ini. Hasil penelitian diketahui bahwa jumlah vang beredar berpengaruh secara signifikan positif terhadap jumlah dana zakat. Dengan demikian dapat disimpulkan jumlah vang beredar berpengaruh siginifikan positif terhadap jumlah dana zakat dan $H_{1}$ diterima. Hubungan positif ditunjukkan oleh koefisien regresi jumlah uang beredar yang memiliki nilai 2190,335 . penelitian ini selaras dengan peneliti yang mendukung teori di atas yakni peneliti Noviyanti (2016) yang menyatakan bahwa "Terdapat hubungan signifikan positif variabel makroekonmi terhadap jumlah penerimaan dana ZIS di Dompet Dhuafa".

Hasil penelitian diketahui bahwa indeks produksi industri berpengaruh secara signifikan positif terhadap jumlah dana zakat. Hal tersebut dapa ditunjukkan dengan nilai $t$ hitung yang lebih besar dengan $t$ tabel yaitu $2,476>1,675$ dengan tingkat signifikansi yang menunjukkan 0,017 lebih kecil daripada 0,05. Sehingga dapat disimpulkan indeks produksi industri berpengaruh siginifikan positif terhadap jumlah dana zakat dan $H_{1}$ diterima. Hubungan positif ditunjukkan dengan koefisien regresi indeks produksi industri yang memiliki nilai 113980328,681.Penelitian ini selaras dengan korelasi antara pertumbuhan ekonomi dengan zakat juga diutarakan oleh penelitian Noviyanti (2016) yang menyatakan bahwa "Terdapat hubungan signifikan positif variabel makroekonomi terhadap pengumpulan dana ZIS Dompet Dhuafa".

\section{Simpulan}

1. Hipotesis penelitian terbukti atas dua variabel yaitu jumlah vang beredar dan indeks produksi industri dan tidak terbukti atas dua variabel yaitu inflasi dan harga emas.

2. Jumlah vang beredar berpengaruh secara signifikan positif terhadap jumlah dana zakat.

3. Indeks produksi industri berpengaruh secara signifikan positif terhadap jumlah dana zakat.

4. Untuk variabel secara simultan $H_{0}$ diterima, artinya jumlah vang beredar dan indeks produksi industri secara simultan atau bersama-sama berpengaruh signifikan terhadap jumlah dana zakat.

Maka saran yang disampaikan pada peneliatian ini adalah : untuk pemerintah agar membuat regulator lebih baik lagi

\section{DAFTAR PUSTAKA}


Anshori, Muslich dan Sri Iswati. 2009. Buku Ajar Metodologi Peneliti Kuantitatif. Surabaya: Airlangga University Press.

Ahmad, Zulfikar Muzakir. 2011. Pengaruh Indikator Makroekonomi Terhadap Besarnya Jumlah Zakat Yang Terkumpul di Lembaga Amil Zakat Dompet Dhuafa Republika Tahun 1993-2009. Tesis tidak diterbitkan. Jakarta. Universitas Indonesia

Al-Zuhayly, Wahbah. 2008. Zakat: Kajian Berbagai Mazhab. Bandung: Remaja Rosdakarya.

Boediono, 1982. Ekonomi Makro Edisi 4. BPFE-UGM: Yogyakarta.

BAZNAS, 20013. Outlook Zakat 2014. Jakarta

BAZNAS, 20016. Outlook Zakat 2017. Jakarta

Chapra, Umer. 2000. Sistem Moneter Islam. Jakarta: Gema Insani Press.

Dwitama, Rio Budi. 2015. Pengaruh Nilai Tukar Rupiah Dan Inflasi Terhadap Jumlah Dana Zakat Di Lembaga Amil Zakat Dompet Dhuafa Periode 19972003. Surabaya: Universitas Airlangga

Fahme, Ahmad, et al. 2015. The Effectiveness of Zakat in Reducing Poverty Incident: An Analysis in Kelantan. Malaysia. Asian Social Science. Vol.11, No.21

Fatma, Fahma Sari. 2005. Pengaruh Inflasi dan Pengangguran terhadap Kemiskinan di Indonesia. Tesis tidak diterbitkan. Jakarta: Universitas Indonesia

Gujarati, Damodar N. 2004. Basic Econometrics (edisi keempat). The McGrawHill Companies.

Huda, Nurul dkk. 2008. Ekonomi Makro Islam: Pendekatan Teoritis. Jakarta: Prenada Media Grup.

Hafidhuddin, Didin. 2002. Zakat dalam Perekonomian Modern. Jakarta: Gema Insani.
Hakim, Abdul. 2001. Statistik Deskriptif untuk Ekonomi dan Bisnis. Yogyakarta: Ekonosia.

Karim, Adiwarman A. 2015. Ekonomi Makro Islami. Jakarta: Rajawali Pers.

Kameel, Ahmad, et al. 2009. Seigniorage of Fiat Money and The Maqasid AlShari'ah: The Compatibility of The Gold Dinar with The Maqasid. Jurnal Muamalat Bil. Vol.2

Kementerian Agama RI. 2014. Al-Qur'an dan Terjemahan untuk Wanita. Penerbit WALI: Oasis Terrace Recident. Jakarta.

Majdi, Hafiz. 2010. Motivation of Paying Zakat On Income: Evidence from Malaysia. International Journal of Economics and Finance, 2 (3): 7684

Nachrowi, D. 2006. Ekonometrika, untuk Analisis Ekonomi dan Keuangan. Jakarta: Lembaga Penerbit FE UI.

Naf'an, 2014. Ekonomi Makro; Tinjauan Ekonomi Syariah. Yogyakarta: Graha llmu.

Noviyanti. 2016. Pengaruh Variabel Makro Terhadap Penerimaan ZIS Dompet Dhuafa. Bogor. Intitut Pertanian Bogor.

Rahardjo, Prathama dan Mandala Manurung. 2001. Teori Ekonomi Makro. Penerbit Fakultas Ekonomi Universitas Indonesia.

Republik Indonesia. 2011. Undang-Undang No.23 Tahun 2011 tentang Pengelolaan Zakat. Lembaran Negara RI Tahun 2011, No. 115. Sekretaria Negara

Rosyidi, Suherman. 2017. Pengantar Teori Ekonomi: Pendekatan Kepada Teori Ekonomi Mikro dan Makro. Jakarta: Rajawali Pers.

Sanusi, Mahmood. 2001. Gold Dinar, Paper Currency and Monetary Stability: An Islamic View. IIUM Law Journal. Vol.9, No.2 
Singgih, Ovina. 2016. Pengaruh Harga

Minyak Dunia terhadap

Pertumbuhan Output, Indeks

Produksi Industri, Indeks Harga Konsumen, Nilai Tukar dan Suku Bunga di Indonesia. Surabaya: Universitas Airlangga

Sukirno, Sadono, 1981, Pengantar Teori Makro Ekonomi, Jakarta; Bina Grafika.

------. 2004. Makroekonomi Teori Pengantar Edisi Ketiga. PT RajaGrafindo

Persada: Jakarta.

Soesastro, Hadi dkk. 2005. Pemikiran dan Permasalahan Ekonomi di Indonesia dalam Setengah Abad Terakhir. Yogyakarta: Kanisius.

Widarjono, Agus. 2010. Analisis Statistika Multivariant Terapan. Yogyakarta: UPP STIM YKPN.

Zaiton, Nurshuhaida. 2013. Implementation Gold Dinar: Is it Feasible? Prosiding Perkem VIII, Jilid 3

http://dsnmui.or.id

http://bi.go.id

http://bps.go.id

http://pusat.baznas.go.id

www.harga-emas.com 